\title{
Intellectual Capital: Its Impact on Financial Performance and Financial Stability of Ghanaian Banks
}

\author{
By Joseph Mensah Onumah ${ }^{*} \&$ King Carl Tornam Duho ${ }^{\dagger}$
}

This paper is an attempt to investigate the effect of intellectual capital (henceforth IC, which is defined using Value Added Intellectual Coefficient (VAIC ${ }^{\mathrm{TM})}$ as discussed in Pulic $(2008,2004,2001,1998)$ on financial performance and financial stability of 32 banks in Ghana from 2000 to 2015. The dataset is an unbalanced panel of 354 observations. The methodology of the paper is to test eight hypotheses related to IC and its components (Human Capital Efficiency or HCE, Structural Capital Efficiency or SCE and Capital Employed Efficiency or CEE) and their relationship with financial performance and financial stability. The paper finds support in favour of the claim that VAIC TM has a positive and significant impact on financial performance and financial stability. On the other hand, among the components of VAIC ${ }^{\mathrm{TM}}$, it is only HCE that behaves in a manner similar to VAICTM. Among the other components, SCE has a negative impact on financial performance and financial stability. CEE has a positive impact on financial performance but a negative impact on financial stability. This implies that SCE reduces both financial performance and financial stability, while CEE increases financial performance but reduces financial stability. Effects of controls, such as leverage, bank size, concentration and ownership structure are discussed in some detail.

Keywords: Bank Performance, Ghana, Intellectual Capital, Risk, VAIC ${ }^{\mathrm{TM}}$.

\section{Introduction}

The history of intellectual capital (IC) can be traced to the 1960s and 1970s when the initial concern about human asset/resource accounting was raised (Roslender and Fincham 2001). The first exposure draft leading to the development of an accounting standard on intangible assets dates back to 1997, the consequent product which is IAS 38: Intangible Assets, the accounting treatment prescribed for intangible assets. Unlike the old economy which was physical capital-based, the current economy is information/knowledge-based. An innovative company doing noteworthy business may be operating in a kiosk with 3 computers, a printer and other electronic appliances and 3 staff, with its resulting operations/outputs hitting country and international headlines. Predominantly in both developed and developing economies, the economic fundamentals have changed resulting in a growing interest in IC which is now a critical element of organisational value. Firm's investment in IC has increased over the years above physical capital investment and is recognized as pivotal lever of wealth creation (Firer and Williams 2003). This has driven the interest in IC measurement, reporting and

${ }^{*}$ Senior Lecturer, University of Ghana Business School, Ghana.

${ }^{\dagger}$ Research Assistant, Department of Accounting, University of Ghana Business School, Ghana. 
disclosures. In general terms, IC is the knowledge-base and creativity of the human mind. This goes beyond investment in copyrights, patents and goodwill, which appear on balance sheets; it includes know-how of staff and even the firm's relation with its key stakeholders. It is an essential measure of the wealth and value of organisations' human ingenuity; often leading to sustainable competitive advantage and sustainable corporate performance. As a result, corporate bodies now have a function for IC management called Chief Knowledge Officer (CKO), and research in this area continues to increase (Inkinen 2015).

Globally, research in IC continues to increase across industries and continents; the industries including banking, insurance, audit, hotel and small and mediumsized enterprises (SMEs). The key focuses of IC studies are on recognition, measurement, disclosure as well as investigation of the impact of IC on various institutional variables including performance, market value or the impact of certain variables including corporate governance (Al-Musalli and Ismail 2012) on IC. Earlier IC studies have been conducted across continents such as Europe (Mention and Bontis 2013, El-Bannany 2008), Asia (Mondal and Ghosh 2012, Lu et al. 2014), Australia (Clarke et al. 2011, Joshi et al. 2010), among others. In Africa, fewer studies have been done in this area. For banks, IC is very essential; first because banks provide myriads of services which are not accounted for by traditional accounting information. For instance, the financial statements fail to show the values of human capital, organisational capital as well as customer capital which are essential building blocks of every firm (Seetharaman et al. 2002). Again, the universal banking license allows for the provision of varied financial services by banks which, although are argued to help diversify risk, require expertise for effective management.

In Ghana, the aftermath of the structural adjustment programme supported by the IMF and World Bank saw the liberalisation of the banking industry. This and technological changes, globalisation and the adoption of the Universal Banking status have together increased competition and performance in the industry. The same factors have made the banking operations complex, justifying the case for prudent risk management. A search through literature however reveals that there is less knowledge about the impact of IC on financial performance and financial stability of banks in Ghana. Earlier IC studies in Ghana were on IC disclosure (Asare et al. 2013, Asare et al. 2014); the only banking study was by Alhassan and Asare (2016) which studied productivity. No Ghanaian banking study investigated the impact of IC and its components on a conventional financial performance measure or on risk over a long study period.

The current study seeks to address two research objectives: 1 ) to examine the impact of IC and its components on financial performance of Ghanaian banks and 2) to examine the impact of IC and its components on financial stability of Ghanaian banks. The study therefore seeks to answer two research questions: 1) Does IC and its components have significant impact on financial performance of Ghanaian banks? 2) Does IC and its components have significant impact on financial stability of Ghanaian Banks? First, this study estimated the IC of banks 
using the VAIC ${ }^{\text {TM }}$ model (Pulic 2001, 1998, 2008, 2004) ${ }^{1}$. The financial stability scores of banks were estimated using the traditional z-score (Hannan and Hanweck 1988, Boyd et al. 1993) and financial performance was measured using return on asset (ROA). The study employed the panel corrected standard error (PCSE) regression technique to investigate the impact of IC on financial performance and financial stability while controlling for leverage, size, competition, government ownership and foreign ownership. The study found evidence to the assertion that IC drives both financial performance and financial stability of banks in Ghana. The result also suggests that Human Capital Efficiency (HCE) is the lifeblood of IC and also a driver of financial performance and financial stability. Capital Employed Efficiency (CEE) is identified to be the next most vital component of IC and triggers increase in financial performance but a decline in financial stability. Structural Capital Efficiency (SCE) was evidenced to be the least important in the industry; it negatively affects financial performance and financial stability. Again, the empirical result indicates that the collusive power of the industry drives the financial performance of the industry but competition is a driver of financial stability.

The remaining parts of the paper are organized as follows: Section two provides a general overview of the evolution of the banking sector in Ghana and a review of empirical literature within the scope of the study. Section three focuses on the methods and data used. The next section presents the empirical results of the study. The penultimate section presented the conclusion of the study. Finally, the implications and recommendations of the study are covered in section six.

\section{Overview of the Banking Industry of Ghana}

There is an over-a-century history of banking activity in Ghana. From the establishment of the first government savings bank (i.e. the British Bank of West Africa now Standard Chartered Bank) in 1896 and the Colonial Bank (now Barclays Bank) in 1917, the banking industry has been liberalised leading to competition. It is worth noting that prior to the establishment of British Bank of West Africa, the Post Office Savings Bank was established in 1887 and was mainly serving the indigenous population (Appiah-Adu and Bawumia 2016). The financial system was clogged with massive state ownership, huge debts to stateowned enterprises, large non-performing loans, a fixed exchange rate system, and a weak central bank by the end of the 1970s (Isshaq and Bokpin 2012). In the 1980s, the Economic Recovery Programme (ERP), the subsequent Financial Sector Adjustment Programme (FINSAP) and Financial Sector Strategy Plan (FINSSP) were launched when the government sought assistance from the World Bank and the International Monetary Fund (IMF). The programme witnessed the introduction of a market with privatized banks and the central government's diversification of interest in most public corporations, deregulation, revitalization

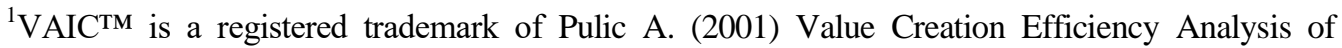
Croatian Banks, 1996-2000. (accessed July 2, 2014).. The VAIC ${ }^{\text {TM }}$ model was first applied on the banking industry of Australia.
} 
and restructuring of the industry. To provide a legal backing of the programme, the Banking Law 1989 (PNDL 225) was enacted to govern the banking industry of Ghana. As a result, there were new entrants into the banking industry.

Figure 1. Timeline of Developments in the Banking Industry up to 2000

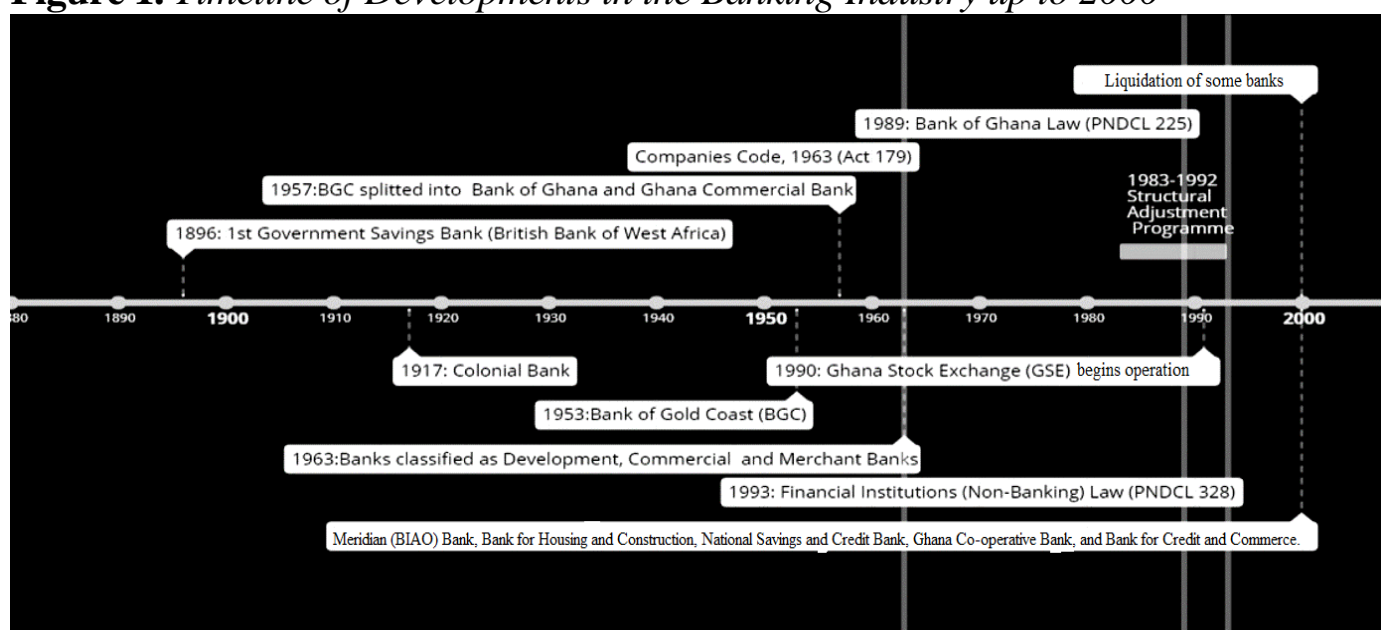

Source: Authors.

In spite of efforts to use legislative and regulatory reforms to enhance the banking industry, in attribution to the real estate losses (Sheng 1996, Sheng and Tannor 1996), Ghana experienced a number of bank liquidations in early 2000 involving banks such as Meridian (BIAO) Bank, Bank for Housing and Construction, National Savings and Credit Bank, Ghana Co-operative Bank, and Bank for Credit and Commerce. The Figure 1 provides a timeline of events up to the year 2000.

There have been various regulatory frameworks aimed at straightening the industry over the last 18 years. An example is the introduction of the Universal Banking License in 2003 which allows banks to carry out comprehensive activities involving investment banking, commercial banking, development banking and insurance among others. Another development is the enactment of the Ghana Deposit Protection Act 2016 (Act 931), which aims at protecting depositors against events of unexpected circumstances, which may result in loss of funds. This Act has been recently amended by the Ghana Deposit Protection (Amendment) Act 2018. The Banks and Specialised Deposit-taking Institutions Act 2016 (Act 930) consolidate all deposit taking laws and regulate deposit-taking institutions. The Bank of Ghana (Amendment) Act 2016 (Act 918) seeks to strengthen the functional autonomy, governance and the Central Bank's ability to respond to banking sector crises. The Act fills the loopholes of the Bank of Ghana Act 2002 (Act 612) and is based on examination of current international trends. The Bank of Ghana in its attempt of executing the Basel II regulatory provisions has given the banks a directive to adopt and apply a risk-based capital adequacy requirement starting from July 2018. As of August 2018, there were 30 licenced banks operating in Ghana. This would have been higher but for the collapse of 
some banks and the merger of others ${ }^{1}$. Figure 2 gives a chronicle of regulatory and policy formulations that have evolved which has subsequently shaped the banking industry in the past 17 years.

Figure 2. Developments in the Banking Industry from 2000-2017

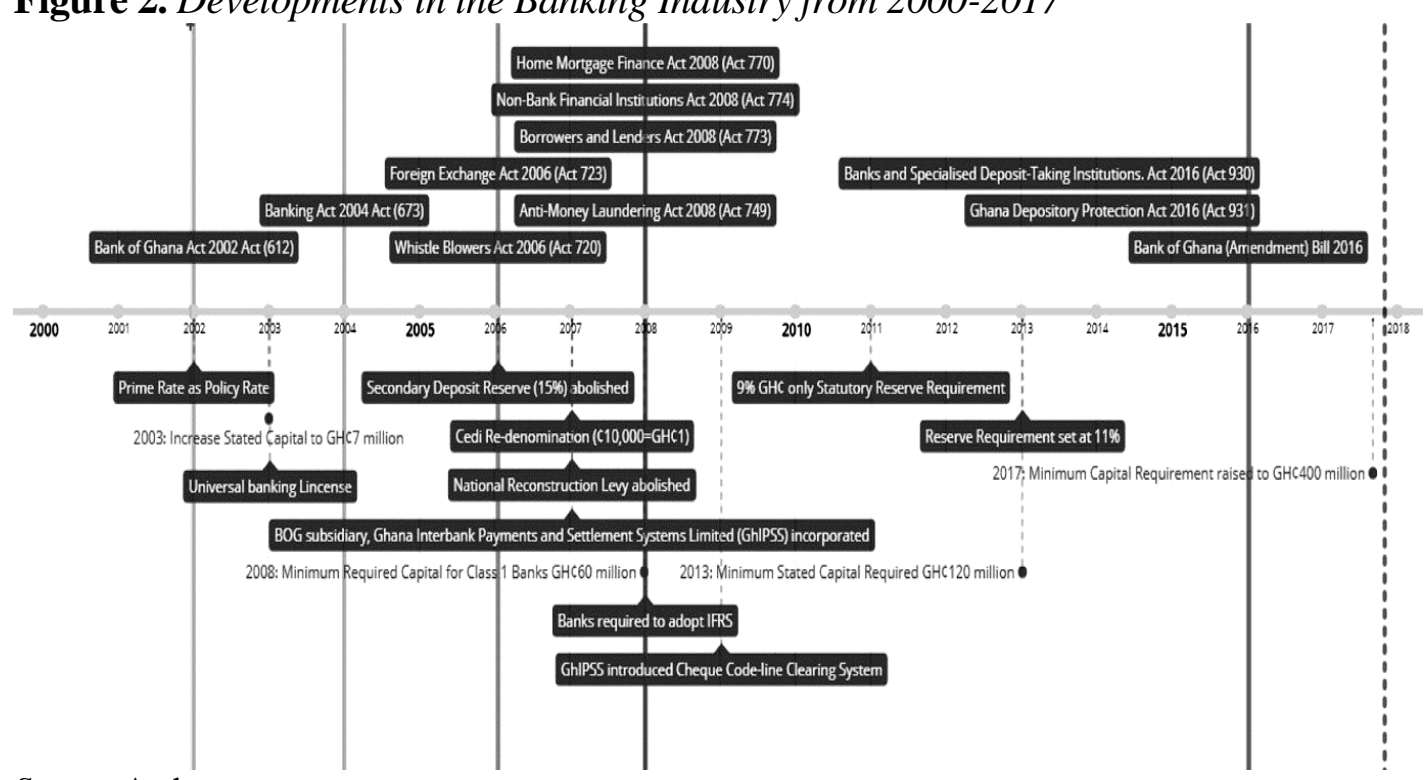

Source: Authors.

\section{Literature Review}

The resource-based view of the firm (Penrose 1959) argues that competitive advantage and greater performance are gained when firms acquire, hold and subsequently use strategic assets. IC indisputably is a key resource of firms in the current knowledge-economy and essentially in knowledge-intensive firms. In spite of the debate on classification, there is consensus that IC is a multidimensional concept, which consists of the firm's human, structural and relational resources (Bontis 1998, Mention and Bontis 2013). Human capital is the skills, knowledge and experience base of employees, which is enhanced through training and development. Structural capital is inseparable knowledge base of the organisation and includes structures, processes, systems, procedures, hardware, patents and even the strategy of the organisation. Relational capital is the relation of the organisation with various stakeholders. Other developments in literature include innovation capital, social capital, technological capital and information capital (Inkinen 2015). In spite of the discussions that grew in this area in both research and practice, there have been little impact on the studies as there was no quantitative measure for the various capitals. Earlier on, there was the employment of the traditional Tobin's Q method, the balanced scorecard approach (Kaplan and Norton 1996) and the intangible asset score card sheet (Sveiby 1989, 1997). Pulic

${ }^{1}$ In 2017, two indigenous banks, UT Bank and Capital Bank were liquidated. In 2018, five other banks were merged into a newly licenced bank, the Consolidated Bank Ghana. 
(2001), based on the stakeholder perspective, developed the VAIC ${ }^{\text {TM }}$ method which provides a quantitative measure of IC for stakeholder's use. The method permits firms to estimate their efficacy and value creation efficiency and has been adopted in various studies across varied industries (Inkinen 2015).

In spite of its common usage in literature, the VAICTM model has been criticized. One of them is Ståhle et al. (2011), which argued that the model merely indicates efficiency of the labour and capital investments of firms and is not a valid measure of IC. Nevertheless, other studies alluded to the significance of the VAIC ${ }^{\text {TM }}$ model. For instance, Joshi et al. (2010) argued that at present, the model is the only essential quantitative model for measuring IC. Again, for the fact that it used data sourced from audited financial statements which are available public data, it suggests that there is much simplicity, verifiability and reliability (Clarke et al. 2011, Zeghal and Maaloul 2010). Essentially, the model also provides information that has scope and is comparable among firms (Nazari and Herremans 2007, Maditinos et al. 2011).

IC studies have been conducted across various continents. In the European literature, Cabrita and Vaz (2005) used a questionnaire on 53 banks to study the IC performance in Portuguese banks and found IC to be prominently associated to organisational performance. The study concluded that structural capital and relational capital positively moderate the human capital and organisational performance link. Similar result was found in Mention and Bontis (2013), which used 200 survey instruments in Luxembourg and Belgium to study IC and performance connection. The results indicated that human capital has direct and indirect impact on business performance. Also, the impacts of structural capital and relational capital were found to be positive but insignificant on IC while relational capital negatively moderates structural capital's contribution on performance. The VAICTM model is employed by a number of studies. ElBannany (2008) investigated the determinants of IC performance in UK from 1999 to 2005 and found that bank profitability and risk are important determinants. The study also found that bank efficiency, investments in IT systems, barriers to entry and efficiency of investments in IC variables have statistically significant impact on IC performance. In a study on 21 banks listed on the Milan Stock Exchange, and using data from 2005 to 2007, Puntillo (2009) found no statistical evidence of an association between business performance measured by return on investment (ROI), return on asset (ROA), market-book-value (MBV) and IC. The only association was evidenced between CEE and the performance measures.

In Asia, the VAIC ${ }^{\text {TM }}$ method has been employed in most studies. Mavridis (2004), in a study in Japan for the period $1^{\text {st }}$ April 2000 to $31^{\text {st }}$ March 2001, confirmed significant performance differences among a range of banks. The study also found the same evidence between Japanese and some European banks (data from Greek and Austrian banks). Using data from 2001 to 2003 in Malaysia, Goh (2005) found that the HCE of banks was relatively higher than CEE and SCE. Also, foreign banks were found to be more efficient than domestic banks. Kamath (2007) used data from 2000 to 2004 to study the Indian banking industry and also found that foreign banks outperformed the domestic ones. Again, while there was overall performance improvement over the study period, the study confirmed that 
performance differed with respect to segments. Using data from 65 banks from 1999 to 2008, Mondal and Ghosh (2012) used ROA and ROE to measure profitability and ATO to measure productivity and confirmed varied associations between IC and these performance indicators. Again, the study concludes that banks' IC is vital for their competitive advantage. Saengchan (2008) found a strong nexus between IC and financial performance of banks in Thailand over the period 2000-2007. The study used cost-total asset (CTA) ratio to proxy efficiency and ROA for profitability. IC was found to be strongly linked to CTA, suggesting that high IC banks are also cost efficient. In the study, HCE was a major factor of cost efficiency and highly negatively correlated. In a study on listed banks in Turkey from 1995 to 2004, Yalama and Coskun (2007) used the VAIC ${ }^{\text {TM }}$ and Data Envelopment Analysis (DEA) and found that the effect of IC on profitability was averagely at $61.3 \%$. The study developed 3 portfolios and found that the portfolio with IC as input yields the highest return. Ghosh and Maji (2014) examined the impact of IC and its components on bank risk in India using data from 1998 to 2012. The study found IC to be inversely associated with credit risk. In the case of insolvency risk, the study found that $\mathrm{z}$-score is positively but insignificantly affected by IC efficiency; suggesting that IC efficiency is negatively related to insolvency risk. The study also found that HCE is positively related to z-score (i.e. negatively related to insolvency risk) but the relationship was insignificant. SCE has a significant positive impact on z-score (i.e. negatively related to insolvency risk).

In Australia, Pulic (2004) revealed that IC and corporate success strongly interact, showing that the banks with high investment in IC perform better financially. In the same industry, Joshi et al. (2010) studied the IC performance of Australian owned banks for the period 2005 to 2007 and found HCE to be higher than CEE and SCE in all banks. In the study, VAICTM related significantly with human cost and value addition. However, it was found that size, total number of employees and total equity had little or no effect on IC.

In Africa, some studies examined the IC study across sectors and not precisely banks (Firer and Williams 2003). In Ghana, earlier IC studies were on IC disclosure (Asare et al. 2014, Asare et al. 2013). Asare et al. (2013) conducted a content analysis on the annual reports of 25 listed companies (bank and non-bank) over the period 2006-2010 and found that disclosure of IC was quite high and reported descriptively. It found that the improvement in IC disclosure was at a marginal rate. In addition, Asare et al. (2014) used the same data and found that the firms in the finance and insurance sector disclose more IC in their annual reports. Using data from 18 banks over the period 2003-2011, Alhassan and Asare (2016) employed the VAIC ${ }^{\text {TM }}$ and DEA to investigate the impact of IC on bank productivity. Employing the Malmquist Productivity Index (MPI) as a measure of productivity, the study found that VAIC ${ }^{\mathrm{TM}}$ has a positive impact on productivity. Also, HCE and CEE are the main component drivers. The earlier study used fewer number of banks over a shorter study period. Also, earlier African studies did not examine the impact of IC on financial stability. Specifically in the Ghanaian context, earlier studies did not use the traditional financial performance ratios. 
The current study is original in drawing an empirical link between IC and financial stability in an emerging economy. Also, the study used data of more banks over a longer period as compared to earlier studies, thus the analysis may provide comparatively more precise results.

\section{Data and Methodology}

There are four parts to this section. The first part describes the model for estimating IC as well as its components in line with the VAIC ${ }^{\text {TM }}$ model of Pulic (2001). The next part discusses the proxies used to measure financial performance and financial stability. The penultimate part outlined the empirical model employed to test the various hypotheses of the study which are developed in the last part. The main data (income statement and statement of financial position) are sourced from the Banking Supervision Department of the Bank of Ghana and cross-validated from the annual reports of banks. Data of 32 banks with 354 observations spanning a 16-year period (2000-2015) was used ${ }^{1}$.

\section{Measuring IC and its Components: The VAIC ${ }^{\mathrm{TM}}$ Model}

To measure IC and its components, the current study applied the VAICTM model of Pulic $(2008,2004,2001,1998)$. The VAIC ${ }^{\text {TM }}$ model is a tripartite model with the components: HCE, SCE and CEE. The model is meant to enable managers and stakeholders effectively monitor how the total resources as well as each resource component at their disposal help to generate value addition. HCE defines the knowledge and skills of the employees which can be augmented by training and development. Examples of these include the technical competence, creativity, personal attributes, leadership skills, business skills, and the people skills of employees which at the micro (individual) level enhance financial performance and financial stability. At the macro (organisational) level, healthy work environment and team work, occupational health and safety, commitment to employee growth and development are some human capital factors. SCE comprises of the systems, databases, structures, processes, procedures, policies, routines, hardware, strategies and the intellectual property of the bank. They are created by the organisation and cannot be separated from the organisation. They have the potential of enhancing the capability of employees but are not linked to employees at the individual level. CEE measures the ability of equity holder's fund to contribute to value creation. Pulic (1998) asserted that IC does not create value in a vacuum but does so when combined by financial (physical) capital. This measure seeks to ascertain the efficiency that has not been measured by both HCE and SCE. IC is ascertained by adding these three components which are HCE, SCE and CEE. The mathematical model for VAIC ${ }^{\text {TM }}$ has been presented in Appendix 1.

\footnotetext{
${ }^{1}$ There were 30 banks in operation as of 2015, 27 of which are used in this study. Also, 5 other banks that existed over the study period but later exited have been included.
} 
The current study adopts the VAIC ${ }^{\text {TM }}$ model since it still offers us an insight into the IC of banks. Also, this is because the arguments in contrast to the method are not mainly because of the insufficiency of the model in itself but because of the difficulty in quantitatively measuring IC.

\section{Measuring Financial Performance and Financial Stability}

Various bank studies employed ROA as dependent variable in their studies to measure financial performance (Tan et al. 2017, Firer and Williams 2003). In this current study, the ratio of Profit Before Tax (PBT) to total asset is used to estimate ROA. The ratio expresses the effectiveness of the bank to take earnings advantage of the asset base at its disposal. High values of this ratio are desirable while lower values are undesirable. Higher values suggest that the management of the bank has been effective in taking advantage of economic resources to increase returns.

The z-score, a measure of insolvency risk, is employed as a measure of financial stability in this study. It was first proposed by Hannan and Hanweck (1988) and used by Boyd et al. (1993). Since then, it has been employed by various studies to investigate the financial stability of banks (Iannotta et al. 2007, Tan and Floros 2013, Tan et al. 2017, Ghosh and Maji 2014). The score considers the return, volatility of return and the capital base of the banks. High z-score suggests financial stability and the ability to absorb losses ${ }^{1}$. The model is given as:

$$
Z S=\frac{R O A+E / A}{\sigma R O A}
$$

where ROA is return on asset, E/A is equity-asset ratio and $\sigma \mathrm{ROA}$ is the standard deviation of ROA.

\section{Empirical Model}

The authors employed the Prais-Winsten panel corrected standard error (PCSE) regression technique of Beck and Katz (1995) to ascertain the impact of IC and its components on financial performance and financial stability of banks in Ghana. The following models are used to ascertain the link.

$$
\begin{aligned}
& \varphi_{i, t}=\alpha_{1}+\delta_{2} \operatorname{VAIC}^{\mathrm{TM}}{ }_{i, t}+\delta_{3} L V_{i, t}+\delta_{4} H_{H I L}+\delta_{i, t} \operatorname{SIZE}_{i, t}+\delta_{6} G O W N_{i, t}+\delta_{7} F O W N_{i, t}+\varepsilon_{i, t} \\
& \varphi_{i, t}=\omega_{1}+\gamma_{2} H C E_{i, t}+\gamma_{3} S C E_{i, t}+\gamma_{4} C E E_{i, t}+\gamma_{5} L E V_{i, t}+\gamma_{6} H H I L_{i, t}+\gamma_{7} S I Z E_{i, t}+\delta_{8} G O W N_{i, t}+\delta_{9} F O W N_{i, t}+\tau_{i, t}
\end{aligned}
$$

where $\varphi$ is the financial performance or financial stability indicator of a bank; $i$ and $t$ are the specific bank and year respectively. VAICTM is value added intellectual coefficient, HCE is the human capital efficiency, SCE is the structural capital

\footnotetext{
${ }^{1}$ The z-score measures financial stability of the banks. High z-score suggests low insolvency risk (high solvency risk and high financial stability) and low Z-score suggests high insolvency risk (low solvency risk and low financial stability)
} 
efficiency, CEE is the capital employed efficiency, LEV is the leverage of the bank, SIZE is the size of the bank, HHIL is the concentration measure of the bank, GOWN is government ownership and FOWN is foreign ownership. For $\varepsilon$ and $\tau$ they are the error terms which are serially correlated along time. Also, $\alpha$ and $\omega$ represent the constant terms while $\delta$ and $\gamma$ are the regression coefficients.

Equation (2) examines the aggregate effect of VAIC ${ }^{\text {TM }}$ (i.e. additive measure of components HCE, SCE and CEE) on financial performance and financial stability. On the other hand, Equation (3) examines the effect of the individual components of VAICTM separately on financial performance and financial stability. Although the aggregate effect of VAICTM might be positive or negative, the individual component drivers of VAIC (i.e. HCE, SCE and CEE) might behave differently. Thus, the regression equations look at the problem in two ways.

\section{Hypotheses Development}

The evolved theoretical links between the dependent variables and the explanatory variables are explored in this section with their resulting hypotheses. A tabular presentation of the relationships between the dependent variables and the explanatory variables has been presented in Appendix 2.

\section{$\underline{\text { IC (VAICTM) and Financial Performance }}$}

The knowledge-based view (KBV) of the firm points out that IC is an essential organisational value and performance driver. Greater advantage is obtained from IC investment than in physical capital in organisations especially in the service sector. IC investment has become a strategic way to enhance competitive advantage and firm value. Empirical studies by Mondal and Ghosh (2012), Saengchan (2008) and Cabrita and Vaz (2005) attributed the positive impact of IC measured by VAIC ${ }^{\text {TM }}$ on performance, save for Puntillo (2009). Our expectation based on theory and empirical results is a positive association between IC, its components (HCE, SCE and CEE) and financial performance. The following hypotheses are therefore tested:

H1. IC is a driver of high financial performance in banks.

H2. HCE is a driver of high financial performance in banks.

H3. SCE is a driver of high financial performance in banks.

H4. CEE is a driver of high financial performance in banks.

\section{$\left.\underline{\text { IC (VAIC }}{ }^{\mathrm{TM}}\right)$ and Financial Stability}

Risk and IC in banking studies are not many. Ghosh and Maji (2014) was the first to consider the nexus, using credit risk and insolvency risk. The role of human capital in risk management in current financial markets that require consistent adjustments to market issues cannot be overemphasized. The human and nonhuman knowledge-base of the organisation is expected to increase efficiency in 
giving out loans and thus reduce the probability of loan loss or insolvency. In line with this argument, we expect a negative link between IC with its components and risk such that high IC leads to lower risk. Thus, high IC is expected to lead to financial stability (high z-score). The following hypotheses are therefore tested:

H5. IC is a driver of high financial stability in banks.

H6. HCE is a driver of high financial stability in banks.

H7. SCE is a driver of high financial stability in banks.

H8. CEE is a driver of high financial stability in banks.

To reduce the effect of other exogenous variables that may explain the observed nexus that IC has on financial performance and financial stability, five control variables (size, concentration, leverage, foreign ownership and government ownership) have been included in the regression model.

\section{Leverage}

Earlier studies employed leverage in IC studies (Zeghal and Maaloul 2010, Firer and Williams 2003). The ratio of total liabilities to total assets is used as proxy for leverage in this study. High leverage can result in banks mainly focusing on meeting the demands of their debtholders. This deviates from the stakeholder view assumed by VAIC ${ }^{\text {тM }}$. Again, banks that employ high debt will consequently have higher obligations to pay interest to debt holders, which could make them less attractive for investors and also highly exposed to the risk of insolvency.

$\underline{\text { Size }}$

A benefit that banks derive from large scale operation is economies of scale. Economies of scale results in decreased cost which can lead to higher firm performance. Again, it can also affect the risk-bearing ability of banks. Large banks are more able to spread their portfolio risks by way of diversification as compared to the smaller banks. The natural logarithm of total assets is used as a proxy for size in this study. This has been employed in other banking studies (Firer and Williams 2003, Alhassan and Asare 2016). Biekpe (2011) provided an empirical evidence of the existence of economies of scale in the banking industry of Ghana.

\section{$\underline{\text { Market Structure }}$}

The Quiet Life Hypothesis (QLH) of Hicks (1935) argues that firms in concentrated markets benefit from a "quiet life" devoid of competition. This in effect negatively impacts performance since banks become inefficient. The inefficiency of managers can also be evidenced in their inability to manage risks. Earlier studies employed the concentration ratio to measure market structure (Alhassan and Asare 2016). The Herfindahl Hirschman Index (HHI) is a better market structure power compared to the concentration ratio. From the product 
market concentration standpoint, this study measures HHI as the sum of squares of market shares of loans of the banks apiece ${ }^{1}$.

\section{Ownership Structure}

Ownership structure can be expressed in various ways. This can be based on foreign and domestic ownership or on government and private ownership. Goh (2005) and Ghosh and Maji (2014) respectively conducted their IC analysis using the ownership structures. For the first measure, a dummy of 1 is used to represent foreign banks and 0 for local banks while for the second measure, a dummy of 1 is used to represent government ownership and 0 for private ownership. Based on the global advantage theory, it is expected that foreign banks will have access to better technologies and expertise. This is expected to have a positive effect on their financial performance and financial stability. Also, management of the banks that are owned by government may be exposed to bureaucracy and external pressures from politicians who may have a negative effect on their financial performance and financial stability.

\section{Empirical Results}

This section discusses the results of the descriptive statistics, the correlation analysis and the regression results to address the research objectives and test the various hypotheses developed for the study.

\section{Descriptive Statistics}

The results of the descriptive statistics presented in Appendix 3 shows that overall, the mean of ROA is $0.031(\mathrm{SD}=0.04)$ suggesting that banks make a return of $3.1 \%$ on total asset, which varies across banks and across years. Also, the result indicates that ZS has an average of 5.435 and varies across bank and years. The result on VAIC ${ }^{\text {TM }}$ and its components show that on average, the VAIC ${ }^{\text {TM }}$ of the banks is at 4.311. HCE contributes an average of 3.022 to VAIC ${ }^{\mathrm{TM}}$. On average, SCE contributes 0.588 to VAIC ${ }^{\text {TM }}$ while CEE contributes 0.681 to VAIC ${ }^{\text {TM }}$. This result differs from that of Alhassan and Asare (2016) which found that on average VAIC $^{\text {TM }}$ was 2.09 ( $\left.\mathrm{SD}=1.94\right), \mathrm{HCE}$ was $1.54(\mathrm{SD}=1.45), \mathrm{SCE}$ was $0.50(\mathrm{SD}=0.40)$ and $\mathrm{CEE}$ was $0.05(\mathrm{SD}=0.03)$. As a result of the superiority of the data used by the current study, the relevance of the components of VAICTM has to be re-established that the second most vital component is $\mathrm{CEE}$ and the third being SCE. The result on LEV indicates that on average, $82.8 \%$ of the asset of the banks is financed by debt. In terms of the size of banks, on average, the total assets of the banks is at $\mathrm{GH} \notin 762$ million and varies across banks and years. Again, the result indicates that

\footnotetext{
${ }^{1}$ The HHI of loans can be computed as $H H I=1000 * \sum_{i=1}^{N} M S_{i}^{2}$ where MS is the market share of total loans of a bank for a specific year.
} 
only few (13.4\%) banks are government owned, with $48.7 \%$ of the banks being foreign owned.

\section{Correlation Analysis}

The pairwise correlation matrix is computed for the explanatory variables to test whether there is the existence of multicollinearity which can lead to wrong inferences. This has been presented in Appendix 4. The results indicated that HCE is highly correlated with VAICTM with a coefficient of 98.1. However, this is not a problem since both VAICTM and HCE will not be included in the same regression models but different models. Apart from that, all the other correlation coefficients are below 0.7. Thus, using the rule of thumb of 0.7 as argued in Kennedy (2008), the regression models will not be perverted by multicollinearity. Moreover, a variance inflation factor (VIF) test has been conducted as presented in Appendix 5. The results are below three which is far below the rule of thumb of ten, suggesting that multicollinearity does not exist. Wooldridge (2016) argues that a VIF below ten suggests that there is no multicollinearity.

\section{Intellectual Capital (IC), Financial Performance and Financial Stability}

The results of the nexus between IC and financial performance, as well as financial stability are presented in Table 1 . VAICTM and also its components were separately regressed on financial performance and financial stability. The panel corrected standard errors (PCSE) regression model was used for the estimations. The model diagnostics as indicated by the Wald Chi-square shows that the variables included in the models affect financial performance and financial stability significantly. Also, the results indicated that R-squared hovers around $37 \%$ and 39\%. The model estimation has been discussed in Appendix 6 .

The results indicated that VAICTM positively and significantly affects financial performance at $1 \%$. This supports our $\mathrm{H} 1$ that IC drives financial performance of banks. The result is consistent with the finding of Mondal and Ghosh (2012) and Alhassan and Asare (2016). This indicates that IC triggers financial performance of banks. This emphasises the importance of IC in increasing innovative capabilities of the banks for augmenting financial performance. The result also indicates that HCE has a positive and significant impact on financial performance at $1 \%$. This is also consistent with our $\mathrm{H} 2$ and with the findings of Alhassan and Asare (2016). This suggests that banks can use their investment in human capital to drive financial performance. In the case of SCE, there is a negative and insignificant impact on financial performance. This is contrary to our $\mathrm{H} 3$ and suggests that SCE is not important for driving financial performance. The result is consistent to some extent with the finding of Mondal and Ghosh (2012) but the difference can be explained by the fact that their study did a year-on-year analysis instead of a pooled analysis. Also, it is contrary to the findings of Alhassan and Asare (2016) which found a positive insignificant nexus but this can be explained by the fact that a productivity measure has been used. Thus, based on these two studies and our results, it is suggested that SCE is not 
important to financial performance measured by profitability as compared to that measured by productivity. CEE has a positive effect on financial performance. However, the nexus is statistically insignificant. This suggests that capital investment positively affect financial performance but slightly.

Table 1. IC, Financial Performance and Financial Stability

\begin{tabular}{|c|c|c|c|c|}
\hline & ROA & $\mathbf{Z S}$ & ROA & $\mathbf{Z S}$ \\
\hline VAIC TM & $\begin{array}{c}0.007 * * * \\
(0.001)\end{array}$ & $\begin{array}{c}0.431 * * * \\
(0.119)\end{array}$ & & \\
\hline HCE & & & $\begin{array}{c}0.007 * * * \\
(0.001)\end{array}$ & $\begin{array}{c}0.548 * * * \\
(0.145)\end{array}$ \\
\hline SCE & & & $\begin{array}{l}-0.006 \\
(0.006)\end{array}$ & $\begin{array}{l}-0.090 \\
(0.600)\end{array}$ \\
\hline CEE & & & $\begin{array}{c}0.007 \\
(0.005)\end{array}$ & $\begin{array}{c}-1.340 * * * \\
(0.391)\end{array}$ \\
\hline LEV & $\begin{array}{c}0.021 * * * \\
(0.008)\end{array}$ & $\begin{array}{c}-2.616^{* * * *} \\
(0.907)\end{array}$ & $\begin{array}{c}0.020 * * \\
(0.008)\end{array}$ & $\begin{array}{c}-1.469^{*} \\
(0.880)\end{array}$ \\
\hline SIZE & $\begin{array}{c}0.013 * * * \\
(0.002)\end{array}$ & $\begin{array}{c}-0.823 * * * \\
(0.206)\end{array}$ & $\begin{array}{c}0.013 * * * \\
(0.002)\end{array}$ & $\begin{array}{c}-0.569 * * * \\
(0.207)\end{array}$ \\
\hline HHIL & $\begin{array}{c}0.446 * * * \\
(0.082)\end{array}$ & $\begin{array}{c}-55.671 * * * \\
(8.652)\end{array}$ & $\begin{array}{c}0.473 * * * \\
(0.082)\end{array}$ & $\begin{array}{c}-40.841 \text { *** } \\
(8.405)\end{array}$ \\
\hline GOWN & $\begin{array}{c}0.001 \\
(0.007)\end{array}$ & $\begin{array}{c}2.000 * * * \\
(0.557)\end{array}$ & $\begin{array}{c}0.000 \\
(0.007)\end{array}$ & $\begin{array}{c}1.912 * * * \\
(0.547)\end{array}$ \\
\hline FOWN & $\begin{array}{c}0.006 \\
(0.005)\end{array}$ & $\begin{array}{c}2.020 * * * \\
(0.419)\end{array}$ & $\begin{array}{c}0.007 \\
(0.005)\end{array}$ & $\begin{array}{c}1.795 * * * \\
(0.424)\end{array}$ \\
\hline CONSTANT & $\begin{array}{c}-0.312 * * * \\
(0.049)\end{array}$ & $\begin{array}{c}25.605 * * * \\
(4.690)\end{array}$ & $\begin{array}{c}-0.310 * * * \\
(0.048)\end{array}$ & $\begin{array}{c}19.629 * * * \\
(4.734)\end{array}$ \\
\hline Banks & 32 & 32 & 32 & 32 \\
\hline Observations & 354 & 354 & 354 & 354 \\
\hline R-squared & 0.366 & 0.309 & 0.389 & 0.338 \\
\hline Wald $\chi^{2}$ & $134.21 * * *$ & $72.72 * * *$ & $137.79 * * *$ & $68.61 * * *$ \\
\hline $\operatorname{AR}(1)$ & $27.508 * * *$ & $48.746 * * *$ & $32.591 * * *$ & $58.837 * * *$ \\
\hline B-P/C-W $\chi^{2}$ & $33.10 * * *$ & $28.76^{* * *}$ & $58.83 * * *$ & $102.12 * * *$ \\
\hline
\end{tabular}

Notes: ROA, return on asset; ZS, z-score; VAIC ${ }^{\text {TM }}$, value added intellectual coefficient; HCE, human capital efficiency; SCE, structural capital efficiency; CEE, capital employed efficiency; LEV, leverage; SIZE, size of bank (logarithm of total assets); HHIL, Herfindahl Hirschman Index of loans; GOWN, government ownership and FOWN is foreign ownership, CONSTANT is the constant variable, AR (1) is first order serial correlation and B-P/C-W is BreuschPagan/Cook-Weisberg test for heteroscedasticity ${ }^{1}$. Standard errors are in parenthesis and are robust to both heteroscedasticity and serial correlation *** $\mathrm{p}<0.01, * * \mathrm{p}<0.05, * \mathrm{p}<0.1$ Source: Authors' Estimation in STATA14².

For the result of the control variables, leverage was found to have a positive and significant effect on financial performance. This suggests that banks that employ high debt are high financial performers. Size has a positive and significant effect on financial performance, which suggests that the banks enjoy the benefit of

\footnotetext{
${ }^{1}$ The heteroscedasticity test is based on the studies of Breusch and Pagan (1979) and Cook and Weisberg (1983).

${ }^{2}$ The authors have applied the asdoc STATA program written by Shah A. (2018) "Asdoc: Create High-Quality Tables in MS Word from Stata Output". to create the tables.
} 
economies of scale which enhances their financial performance. Concentration of banks has a positive and significant effect on financial performance. Thus, high competition reduces the financial returns of the banks, suggesting that bank profitability is driven by the collusive power of banks in the industry rather than on efficiency. Government ownership of banks has a positive impact in financial performance, suggesting that government owned banks are relatively high financial performers. This can be as a result of the benefits that government owned banks enjoy because of their association to government. For instance, many government payments (e.g. government workers' salary payments) are carried out through government banks and thus will serve as an advantage for the banks as compared to the private banks. Foreign ownership has a positive and insignificant effect on financial performance. This suggests that foreign ownership slightly triggers high financial performance and is consistent with the finding of Goh (2005) and Kamath (2007). There have been many innovative initiatives that have been brought into the banking industry over the past years by foreign banks, which can explain their high financial performance as compared to their local counterparts.

The results of this current study provide additional insight into the IC and financial stability nexus as studied by Ghosh and Maji (2014). The results of this current study indicated that VAIC ${ }^{\text {TM }}$ has a positive significant impact on financial stability (i.e. negative effect on insolvency risk) at 1 percent. This is consistent with our H5. Although Ghosh and Maji (2014) also established a positive relationship, the relationship was insignificant. Also, their study used a different measure of IC (i.e. HCE+SCE). Our result indicates that IC performance triggers financial stability. As regards the impact of HCE on financial stability, there is a positive significant relationship at 1 percent which is in support of our H6. This is also similar to the positive relationship evidenced in Ghosh and Maji (2014) except for the insignificant relationship they found. This suggests that banks that have employees with technical skills, business skills, leadership skills, people skills and have an organisational environment that encourages learning and development are likely to be financially stable. This is very essential especially in the Ghanaian context where non-performing loans have been a major drawback to the financial stability of the industry. The argument here is that high human capital investment will result in better risk management, loan management, capital structure decision, working capital decisions which could have consequences on financial stability. SCE has a negative and insignificant effect on financial stability. This is contrary to our H7 and the finding of Ghosh and Maji (2014). The finding suggests that structural capital is not a positive driver of financial stability. Thus, the organisational culture, systems, policies, procedures and structures in the banking industry are not positive drivers of financial stability. CEE has a negative and significant effect on financial stability. This does not support our H8 and suggesting that financial capital does not drive financial stability. Thus, the ability of shareholders' fund to create value does not trigger financial stability. An attempt of managers to meet the needs of shareholders without considering the needs of other stakeholders will undermine the financial stability of the industry. 
In terms of the control variables, leverage has a negative and significant effect on financial stability. This suggests that high debt in the capital structure of banks will trigger financial instability. This supports the regulatory decision of Bank of Ghana to adopt the Basel II framework and the increase of the minimum capital requirements of the banks to $\mathrm{GH} \phi 120$ million in 2013 and $\mathrm{GH} \not 400$ million in 2017. Size has a negative and significant effect on financial stability. This suggests that banks are not able to attain risk-bearing economies of scale. Concentration has a negative and significant effect on financial stability. This suggests that competition induces financial stability. Government ownership has a positive and significant effect on financial stability. This suggests that government ownership enhances financial stability. Foreign ownership has a positive and significant effect on financial stability. This also suggests that foreign ownership enhances financial stability of banks.

\section{Conclusion}

In the current knowledge-based economy, the focus of businesses is not only on their financial capital. Their focus is on all the various capitals that have the potential of enabling them earn competitive advantage, increased financial performance and financial stability. In banking, the issuance of the Basel Accords emphasis the need for capital efficiency, risk management and revenue growth. Banks employ various intellectual assets such as human capital, structural capital and relational capital to improve their financial performance, financial stability and innovative capacity.

This study investigates the impact of IC and its components on financial performance and financial stability of banks using an unbalanced panel data of 32 banks with 354 observations over the study period 2000-2015. The Panel Corrected Standard Errors (PCSE) regression model was used to study the impact while controlling for leverage, size, concentration, foreign ownership and government ownership. The study is unique in that it employed data of 27 (90\%) of the banks in operation in 2015 and 5 other banks that have exited the industry over the study period. The study period is 16 years as compared to Alhassan and Asare (2016) which used a study period of 9 years and 18 banks. As we increased the sample size, the precision of our results also increases. Again, the current study is original in examining the relationship between IC and financial stability in Africa. The study has controlled for concentration for both financial performance and financial stability using the Herfindahl Hirschman Index which is superior to the concentration ratio. Finally, the ownership structures of banks have been considered in this study. Some earlier studies either did not include them or conducted their analysis based on the ownership structures without including ownership as a control variable.

On the results of VAICTM, the study found that the IC performance of banks results mostly from HCE. This suggests that the abilities, knowledge and skills of employees of the banks are the driving force of financial performance. Thus, in support for the resource-based theory, the ability of banks to have efficient human 
capital will earn them sustained competitive advantage and consequently increased financial performance. The second most important component is CEE which measures the value creating ability of financial capital of shareholders. The least contributing constituent is the SCE. This is contrary to the finding of Alhassan and Asare (2016) which used fewer data and found that SCE is the second most important constituent and CEE is the least. The study also found that overall, the average financial stability (z-score) of the industry over the study period is somewhere around 5.4.

The empirical result of the impact of IC on financial performance reveals that IC drives financial performance. This supports the resource-based view which argues that IC is essential in increasing sustainable competitive advantage which eventually results in increased financial performance. HCE was evidenced to be the most contributing factor in driving financial performance. Thus, banks that are unable to harness the potentials of their employees in creating value will perform abysmally in terms of financial performance. CEE has a positive effect on financial performance. Although this relationship was insignificant, the positive relationship suggests banks that are able to create more value from shareholder's capital have increased financial performance.

In the case of the impact of IC on financial stability, the empirical evidence reveals that IC is the lifeblood of financial stability. HCE is evidenced to be the most important IC factor that drives the financial stability of banks. This reveals the importance of experience, skills and abilities of employees in effective risk management. SCE negatively affects financial stability. Although the effect is not significant, the result suggests that corporate culture, systems, processes and procedures do not drive the financial stability of banks. This result may suggest that the structural capital of banks in Ghana do not provide a conducive environment for effective risk management. Thus, there is the need for the banks to ensure the development of a corporate culture and internal control systems that ensure effective risk management. This can be effectively done by employing best practice corporate governance principles. This finding may provide barking to the reason for the collapse of some banks in recent banks, by asserting that it is because of poor corporate culture and poor corporate governance. CEE was found to have a significant negative impact on financial stability. This suggests that the ability of financial capital to create value inhibits financial stability. Thus, overfocusing on shareholder value creation at the expense of the other stakeholders may result in undermining financial stability.

For the result of the control variables, the study suggests that banks that employ high debt are high financial performers. However, high debt in the capital structure of banks may trigger financial instability. This backs the adoption and implementation of the Basel II framework by the Bank of Ghana which took off from 2018. It also supports the increase of the minimum capital requirements of the banks to $\mathrm{GH} \phi 120$ million in 2013 and $\mathrm{GH} \phi 400$ million in 2017. Banks were found to be enjoying the benefit of economies of scale which enhances their financial performance. However, the banks may be unable to attain risk-bearing economies of scale. High competition reduces the financial returns of the banks. This suggests that bank profitability is driven by the collusive power of banks in 
the industry rather and not efficiency. Yet, competition in the industry induces financial stability. Government owned banks are relatively high financial performers but are more financially stable. Foreign ownership slightly triggers high financial performance but it highly results in financial stability supporting the global advantage theory.

\section{Implication of Findings and Recommendations}

The study has implications for policy and practice. It suggests that investment in IC is a force to reckon with and is a driver of financial performance and financial stability. Generally speaking, investment in training and development of employees pays off. Thus, bank managers should take steps to involve in better human capital investment that will end up increasing the financial performance and financial stability of the banks. Management should exploit the benefits of SCE as well as CEE to enhance their financial performance and financial stability. SCE can be enhanced by putting in place various internal controls processes through the application of corporate governance best practices. The banks should consider the stakeholder view so as to reap the benefits of IC. Thus, the needs of not only the shareholders but also the employees, customers, investors, debtholders should be considered and by so doing increased financial performance and financial stability will be attained. The banks should attempt to report on IC so as to monitor their IC performance and also derive the benefits from the competitive advantages that IC yields. This is very essential because the next phase of corporate reporting is about how value is created by businesses. In so doing, the International Integrated Reporting Council's (IIRC) framework of capitals and how they help create value can be adopted. The regulator should also monitor the IC performance of the banks to ensure that banks have the prerequisite knowledge-base and internal processes and systems to be able to conduct effective and efficient bank management and most especially monitor risk since the regulator is poised towards enhancing effective risk management in order to foster financial stability and create a resilient financial industry. Competition in the industry should be fostered by the regulator since it serves as a recipe to financial stability.

In spite of the relevant results provided by the study, it is not without limitations. First, the employment of the VAIC ${ }^{\mathrm{TM}}$ model has been criticised by some researchers because of its inability to measure relational capital and for the fact that where negative value added is obtained by banks, the VAIC ${ }^{\mathrm{TM}}$ results become difficult to interpret. Also, the study employed the profitability ratio to ascertain financial performance, other measures such as efficiency scores (technical efficiency, cost efficiency, revenue efficiency, profit efficiency) can be estimated using parametric or non-parametric approaches to measure financial performance of banks. There have been efforts by some scholars to produce an extended VAIC model (Nazari and Herremans 2007), other studies can use such models to exploit the impact of IC on dependent variables. Also, the relationship between IC and competition, corporate governance, research and development can 
be examined by subsequent studies. Another area for further study is the investigation of the determinants of IC. This current study was conducted using data on the banking industry of Ghana, other studies can cover the firms listed on the Ghana Stock Exchange, multinational companies or small and medium-sized enterprises (SMEs) can also be considered. Other banking studies can conduct a content analysis of the annual statement of the banks to examine their IC reportage over the years. More so, cross-country studies will also provide more insight by including various economic, regulatory or regional differences. Thus, further studies can explore the various industries in Sub-Saharan Africa (SSA), or other economic or regional blocs.

\section{Acknowledgements}

The authors gratefully acknowledge the financial support from the University of Ghana Business School and the Office of Research, Innovation and Development (ORID) of the University of Ghana. We also thank the Editor and the anonymous referees for their constructive comments and helpful feedback on an earlier version of the paper. We appreciate the comments of the participants of the 13th Annual International Symposium on Economic Theory, Policy and Applications held in Athens, Greece. The usual disclaimer holds.

\section{References}

Al-Musalli MAK, Ismail K (2012) Corporate Governance, Bank Specific Characteristics, Banking Industry Characteristics, and Intellectual Capital (IC) Performance of Banks in Arab Gulf Cooperation Council (GCC) Countries. Asian Academy of Management Journal of Accounting and Finance 8(1): 115-135.

Alhassan AL, Asare N (2016) Intellectual Capital and Bank Productivity in Emerging Markets: Evidence from Ghana. Management Decision 54(3): 589-609. doi: 10.1108/ MD-01-2015-0025.

Appiah-Adu K, Bawumia M (2016) Key Determinants of National Development: Historical Perspectives and Implications for Developing Economies. New York: Routledge.

Asare N, Onumah J, Simpson S (2013) Exploring the Disclosure of Intellectual Capital in Ghana: Evidence from Listed Companies. Journal of Accounting \& Marketing 2(3): 107.doi:10.4172/2168-9601.1000107.

Asare N, Onumah JM, Otieku JK (2014) Industry Intellectual Capital Disclosure on the Ghana Stock Exchange. IUP Journal of Accounting Research \& Audit Practices 13(4): 36-59.

Beck N, Katz JN (1995) What to Do (and Not to Do) with Time-Series Cross-Section Data. American Political Science Review 89(3): 634-647. Doi: 10.2307/2082979.

Biekpe N (2011) The Competitiveness of Commercial Banks in Ghana. African Development Review 23(1): 75-87.

Bontis N (1998) Intellectual Capital: An Exploratory Study That Develops Measures and Models. Management Decision 36(2): 63-76. doi: 10.1108/002517498102. 
Boyd JH, Graham SL, Hewitt RS (1993) Bank Holding Company Mergers with Nonbank Financial Firms: Effects on the Risk of Failure. Journal of Banking \& Finance 17(1): 43-63.

Breusch TS, Pagan AR (1979) A Simple Test for Heteroscedasticity and Random Coefficient Variation. Econometrica: Journal of the Econometric Society 47(5): 12871294.

Cabrita MdR, Vaz JL (2005) Intellectual Capital and Value Creation: Evidence from the Por-Tuguese Banking Industry. Electronic Journal of Knowledge Management 4(1): $11-20$.

Clarke M, Seng D, Whiting RH (2011) Intellectual Capital and Firm Performance in Australia. Journal of Intellectual Capital 12(4): 505-530.

Cook RD, Weisberg S (1983) Diagnostics for Heteroscedasticity in Regression. Biometrika 70(1): 1-10.

El-Bannany M (2008) A Study of Determinants of Intellectual Capital Performance in Banks: The UK Case. Journal of Intellectual Capital 9(3): 487-498. doi: 10.1108/14 6919308108.

Firer S, Williams MS (2003) Intellectual Capital and Traditional Measures of Corporate Performance. Journal of Intellectual Capital 4(3): 348-360. doi: 10.1108/146919303 10487806.

Ghosh SK, Maji SG (2014) The Impact of Intellectual Capital on Bank Risk: Evidence from Indian Banking Sector. IUP Journal of Financial Risk Management 11(3): 18.

Goh CP (2005) Intellectual Capital Performance of Commercial Banks in Malaysia. Journal of Intellectual Capital 6(3): 385-396.

Hannan TH, Hanweck GA (1988) Bank Insolvency Risk and the Market for Large Certificates of Deposit. Journal of Money, Credit and Banking 20(2): 203-211.

Hicks JR (1935) Annual Survey of Economic Theory: The Theory of Monopoly. Econometrica: Journal of the Econometric Society 3(1): 1-20.

Iannotta G, Nocera G, Sironi A (2007) Ownership Structure, Risk and Performance in the European Banking Industry. Journal of Banking \& Finance 31(7): 2127-2149. doi: 10.1016/j.jbankfin.2006.07.013.

Inkinen H (2015) Review of Empirical Research on Intellectual Capital and Firm Performance. Journal of Intellectual Capital 16(3): 518-565. doi: 10.1108/JIC-012015-0002.

Isshaq Z, Bokpin GA (2012) Expansion and Efficiency in Banking: Evidence from Ghana. Managerial and Decision Economics 33(1): 19-28.

Joshi M, Cahill D, Sidhu J (2010) Intellectual Capital Performance in the Banking Sector: An Assessment of Australian Owned Banks. Journal of Human Resource Costing \& Accounting 14(2): 151-170. doi: 10.1108/14013381011062649.

Kamath BG (2007) The Intellectual Capital Performance of the Indian Banking Sector. Journal of Intellectual Capital 8(1): 96-123.

Kaplan RS, Norton DP (1996) Using the Balanced Scorecard as a Strategic Management System. Boston: Harvard Business Review.

Kennedy P (2008) A Guide to Econometrics. Oxford: Blackwell Publishing.

Lu W-M, Wang W-K, Kweh QL (2014) Intellectual Capital and Performance in the Chinese Life Insurance Industry. Omega 42(1): 65-74. doi: http: 10.1016/j.omega.20 13.03.002.

Maditinos D, Chatzoudes D, Tsairidis C (2011) The Impact of Intellectual Capital on Firms' Market Value and Financial Performance. Journal of Intellectual Capital 12(1): 132-151. 
Mavridis DG (2004) The Intellectual Capital Performance of the Japanese Banking Sector. Journal of Intellectual Capital 5(1): 92-115.

Mention A-L, Bontis N (2013) Intellectual Capital and Performance within the Banking Sector of Luxembourg and Belgium. Journal of Intellectual Capital 14(2): 286-309.

Mondal A, Ghosh SK (2012) Intellectual Capital and Financial Performance of Indian Banks. Journal of Intellectual Capital 13(4): 515-530.

Nazari JA, Herremans IM (2007) Extended Vaic Model: Measuring Intellectual Capital Components. Journal of Intellectual Capital 8(4): 595-609.

Penrose E (1959) Theory of the Growth of the Firm. New York: John Wiley \& Sons.

Pulic A (1998) Measuring the Performance of Intellectual Potential in Knowledge Economy. $2^{\text {nd }}$ McMaster Word Congress on Measuring and Managing Intellectual Capital by the Austrian Team for Intellectual Potential.

Pulic A (2001) Value Creation Efficiency Analysis of Croatian Banks, 1996-2000. [Accessed 2 July 2014].

Pulic A (2004) Intellectual Capital-Does It Create or Destroy Value? Measuring Business Excellence 8(1): 62-68. doi: 10.1108/13683040410524757.

Pulic A (2008) The Principles of Intellectual Capital Efficiency-a Brief Description. Inspired by Knowledge in Organisations: Essays in Honor of Professor Karl-Erik Sveiby on his $60^{\text {th }}$ Birthday 29th June 2008.

Puntillo P (2009) Intellectual Capital and Business Performance. Evidence from Italian Banking Industry. Electronic Journal of Corporate Finance 4(12): 97-115.

Roslender R, Fincham R (2001) Thinking Critically About Intellectual Capital Accounting. Accounting, Auditing \& Accountability Journal 14(4): 383-399.

Saengchan S (2008) The Role of Intellectual Capital in Creating Value in the Banking Industry. International Review of Business Research 7(2): 157-169.

Seetharaman A, Hadi HBZS, Saravanan A (2002) Intellectual Capital Accounting and Reporting in the Knowledge Economy. Journal of Intellectual Capital 3(2): 128-148.

Shah A (2018) "Asdoc: Create High-Quality Tables in Ms Word from Stata Output". Retrieved from https://bit.ly/2CklUZ2.

Sheng A (1996) Bank Restructuring: Lessons from the 1980s: World Bank Publications.

Sheng A, Tannor AA (1996) Ghana's Financial Restructuring, 1983-91. In A Sheng (ed) Bank Restructuring: Lessons from the 1980s, 123-132. Washington: The World Bank.

Ståhle P, Ståhle S, Aho S (2011) Value Added Intellectual Coefficient (Vaic): A Critical Analysis. Journal of Intellectual Capital 12(4): 531-551.

Sveiby KE (1989) The Invisible Balance Sheet. Stockholm: Affarfgarblen.

Sveiby KE (1997) The Intangible Assets Monitor. Journal of Human Resource Costing \& Accounting 2(1): 73-97.

Tan Y, Floros C (2013) Risk, Capital and Efficiency in Chinese Banking. Journal of International Financial Markets, Institutions and Money 26(2013): 378-393.

Tan Y, Floros C, Anchor J (2017) The Profitability of Chinese Banks: Impacts of Risk, Competition and Efficiency. Review of Accounting and Finance 16(1): 86-105.

Wooldridge JM (2002) Econometric Analysis of Cross Section and Panel Data, Cambridge, MA: MIT Press.

Wooldridge JM (2016) Introductory Econometrics: A Modern Approach, Boston: Cengage.

Yalama A, Coskun M (2007) Intellectual Capital Performance of Quoted Banks on the Istanbul Stock Exchange Market. Journal of Intellectual Capital 8(2): 256-271.

Zeghal D, Maaloul A (2010) Analysing Value Added as an Indicator of Intellectual Capital and Its Consequences on Company Performance. Journal of Intellectual Capital 11(1): 39-60. 


\section{Appendices}

Appendix 1. Measuring IC and its Components: The VAIC ${ }^{\mathrm{TM}}$ Model

Value added (VA) reflects the contribution of management and employees to value creation. When total bank revenue, including interest income, and fees and commission, is represented by OUTPUT and the operating cost, including interest expenses, finance and administration expenses excluding personnel expenses (it is rather treated as an investment), is represented by INPUT, VA can be expressed mathematically as:

$V A=O U T P U T-I N P U T$

With this, we can break down each component of VAIC ${ }^{\text {TM }}$ in a ratio form as:

$\mathrm{HCE}=\mathrm{VA} / \mathrm{HC}$

Where $\mathrm{HC}$ is human capital, personnel expenses herein treated as investment.

$\mathrm{SCE}=\mathrm{SC} / \mathrm{VA}$

Where SC is structural capital, VA less HC

$\mathrm{CEE}=\mathrm{VA} / \mathrm{CE}$

Where capital employed is the book value of the firm's total net assets.

The variables are expressed as follows:

1. HCE - indicating the value added (VA) efficiency of human capital

2. SCE - indicating the VA efficiency of structural capital

3. CEE - indicating the VA efficiency of capital employed.

The VAICTM model is then formalized as:

$V A I C^{\mathrm{TM}}{ }_{i}=H C E_{i}+S C E_{i}+C E E_{i}$

Where:

VAICTM $_{\mathrm{i}}$ is the value added intellectual coefficient of bank $i$.

$\mathrm{HCE}_{\mathrm{i}}$ is the human capital coefficient of bank $i$.

$\mathrm{SCE}_{\mathrm{i}}$ is the structural capital coefficient of bank $i$.

$\mathrm{CEE}_{\mathrm{i}}$ is the capital employed coefficient of bank $i$.

It is also worth noting that HCE + SCE yield the intellectual capital efficiency (ICE) coefficient (Pulic, 2008). 
Appendix 2. Relationships between Dependent Variables and Explanatory Variables

\begin{tabular}{lcc} 
& \multicolumn{2}{c}{ Expected Signs } \\
& ROA & ZS \\
VAICTM & + & + \\
HCE & + & + \\
SCE & + & + \\
CEE & + & + \\
LEV & - & - \\
SIZE & + & + \\
HHIL & - & - \\
GOWN & - & - \\
FOWN & + & +
\end{tabular}

Source: Authors.

Appendix 3. Summary Statistics of Model Variables

$\begin{array}{lccccc}\text { Variable } & \text { Obs } & \text { Mean } & \text { Std.Dev. } & \text { Min } & \text { Max } \\ \text { ROA } & 359 & 0.031 & 0.040 & -0.171 & 0.181 \\ \text { ZS } & 359 & 5.435 & 3.880 & -5.107 & 30.965 \\ \text { VAICTM } & 354 & 4.311 & 3.133 & -2.827 & 33.263 \\ \text { HCE } & 356 & 3.022 & 2.959 & -1.628 & 32.075 \\ \text { SCE } & 354 & 0.588 & 0.380 & -3.119 & 2.435 \\ \text { CEE } & 356 & 0.681 & 0.471 & -0.538 & 4.537 \\ \text { LEV } & 359 & 0.828 & 0.174 & 0.090 & 1.937 \\ \text { SIZE }(\mathrm{GH} \phi) & 359 & 7.62 \mathrm{e}+08 & 1.00 \mathrm{e}+09 & 884000 & 6.59 \mathrm{e}+09 \\ \text { HHIL } & 359 & 0.090 & 0.035 & 0.056 & 0.183 \\ \text { GOWN } & 359 & 0.134 & 0.341 & 0.000 & 1.000 \\ \text { FOWN } & 359 & 0.487 & 0.501 & 0.000 & 1.000\end{array}$

Notes: ROA, return on asset; ZS, z-score; VAIC ${ }^{\mathrm{TM}}$, value added intellectual coefficient; HCE, human capital efficiency; SCE, structural capital efficiency; CEE, capital employed efficiency; LEV, leverage; SIZE, size of bank; HHIL, Herfindahl Hirschman Index of loans; GOWN, government ownership and FOWN is foreign ownership.

Source: Authors' Estimation in STATA14. 
Appendix 4. Correlation Matrix for Explanatory Variables

\begin{tabular}{|c|c|c|c|c|c|c|c|c|c|}
\hline Variables & (1) & (2) & (3) & (4) & (5) & (6) & (7) & (8) & (9) \\
\hline (1) VAIC & 1.000 & & & & & & & & \\
\hline (2) $\mathrm{HCE}$ & $0.981 * * *$ & 1.000 & & & & & & & \\
\hline (3) SCE & $0.341 * * *$ & $0.225 * * *$ & 1.000 & & & & & & \\
\hline (4) $\mathrm{CEE}$ & $0.214 * * *$ & 0.070 & 0.046 & 1.000 & & & & & \\
\hline (5) LEV & $-0.138 * * *$ & $-0.178 * * *$ & -0.084 & $0.303 * * *$ & 1.000 & & & & \\
\hline (6) SIZE & 0.041 & 0.034 & -0.019 & $0.102 *$ & 0.068 & 1.000 & & & \\
\hline (7) HHIL & 0.039 & -0.017 & $0.128 * *$ & $0.266 * * *$ & 0.060 & $-0.691 * * *$ & 1.000 & & \\
\hline (8) GOWN & -0.053 & -0.066 & -0.058 & $0.126^{* *}$ & -0.033 & $0.186^{* * *}$ & 0.069 & 1.000 & \\
\hline (9) FOWN & $0.170 * * *$ & $0.176^{* * *}$ & $0.157 * * *$ & $-0.153 * * *$ & $-0.111 * *$ & 0.036 & $-0.094 *$ & $-0.383 * * *$ & 1.000 \\
\hline
\end{tabular}

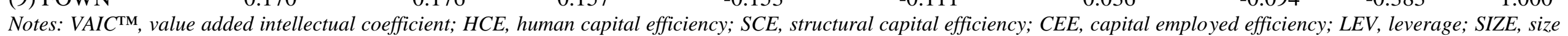
of bank (logarithm of total assets); HHIL, Herfindahl Hirschman Index of loans; GOWN, government ownership and FOWN is foreign ownership.

Source: Authors' Estimation in STATA14. 
ROA and ZS

$\begin{array}{lll}\text { SIZE } & 2.263 & 0.442 \\ \text { HHIL } & 2.167 & 0.461 \\ \text { GOWN } & 1.353 & 0.739 \\ \text { FOWN } & 1.238 & 0.808 \\ \text { LEV } & 1.081 & 0.925 \\ \text { VAICTM } & 1.068 & 0.936 \\ \text { Mean VIF } & 1.528 & 0.936 \\ \text { ROA and ZS } & & \\ \text { HHIL } & 2.708 & 0.369 \\ \text { SIZE } & 2.621 & 0.382 \\ \text { CEE } & 1.427 & 0.701 \\ \text { GOWN } & 1.357 & 0.737 \\ \text { FOWN } & 1.275 & 0.784 \\ \text { LEV } & 1.179 & 0.848 \\ \text { HCE } & 1.130 & 0.885 \\ \text { SCE } & 1.111 & 0.900 \\ \text { Mean VIF } & 1.601 & 0.900\end{array}$

Source: Authors' Estimation in STATA14.

\section{Appendix 6. Model Estimation}

We applied the panel corrected standard errors (PCSE) regression technique of Beck and Katz (1995). This technique assumes that disturbances are by default contemptuously correlated across panels and heteroskedastic in computing the variance-covariance estimates and standard errors. The diagnostic tests conducted for autocorrelation and heteroscedasticity using the serial correlation discussed by Wooldridge (2002) and Breusch-Pagan/Cook-Weisberg Lagrange multiplier test respectively reveals that there is the existence of first-order autocorrelation and heteroscedasticity. Thus, our model has specified both autocorrelation and heteroscedasticity and thus computes the Prais-Winsten PCSE estimates instead of the ordinary least squares PCSE estimates. The study thus favours this technique over the fixed effort and random effect models. Although the Hausman specification test we conducted supported the use of fixed effect in this case, the fixed effect provides results by excluding the ownership structure variables which are relevant for our study as being serially correlated. 
